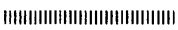

研究論文

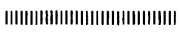

\title{
汪ら酸アルミニウムウィスカ強化6061アルミニウム合金の 機械的性質に及ぼす熱処理の効果
}

斎藤 尚文* ${ }^{*}$ 中西 勝* ·西田 義則*

Effect of heat treatment on the mechanical properties of aluminum-borate whisker reinforced 6061 aluminum alloy

Naobumi SAITO*, Masaru NAKANISHI* and Yoshinori NISHIDA*

\begin{abstract}
Effect of heat treatment (solution treatment and aging treatment at $443 \mathrm{~K}$ ) on the tensile strength between room temperature and $773 \mathrm{~K}$ was investigated of the aluminum-borate whisker reinforced $\left(V_{f}=0.16\right.$ and 0.29$) 6061$ aluminum alloys. Tensile strength of the as-cast $0.29 V_{f}$ composite is in the measured temperature range about twice higher than that of the matrix alloy. No whiskers are observed on the fracture surfaces of the composites up to $573 \mathrm{~K}$. Both tensile strengths of the matrix alloy and of the $0.29 V_{f}$ composite are increased by aging treatment. The degree of the increase is, however, smaller for the composite than the matrix alloy. In the heat-treated composites, whiskers are observed on the fracture surfaces. This result shows that the strength of matrix alloy/whisker interface is decreased by the heat treatment.
\end{abstract}

Keywords: metal matrix composite, aluminum-borate whisker, 6061 aluminum alloy, tensile strength, effect of heat treatment

(Received June 28, 1993)

\section{1. 緒 言}

近年，一般工業用材料として使用する目的で，金属基 複合材料が広く研究されている。ことに, アルミニウム 合金をマトリックスとし, 七ラミックス粒子や繊維, ウ ィスカを強化材とした複合材料の開発, 製造が検討され ている。このよらなアルミニウム合金基複合材料は，自 動車のエンジンなどの高温用構造材料の軽量化および高 温化に対応する材料として期待されている。しかし，ア ルミニウム合金基複合材料を実用材として用いるために は，製造コストを低く抑えることが望ましい。したがっ て, 使用される強化材の種類は限られてくるであろら。 その点において, 近年開発されたほら酸アルミニウム ウィスカは, 実用化に最も近い金属基複合材料用の強化 材として期待されている。それはこのウィスカが，(1)炭 化けい素ウィスカと同等の強度を持つ, (2)密度が炭化け い素ウィスカや窒化けい素ウィスカよりも小さい, (3)価 格も炭化けい素ウィスカや窒化けい素ウィスカに比べて
低い，といった特徵を持つからである。しかし，汪う酸 アルミニウムウィスカ強化アルミニウム合金の特性や機 械的性質に関しては，まだ数例の報告があるだけであ $3^{1) \sim 4)}$ 。

菅沼ら ${ }^{11}$ はAC8A アルミニウム合金とほう酸アルミニ ウムウィスカの複合材を作製し，強度特性と耐熱特性を 調べた。その結果, この複合材は $573 \mathrm{~K}$ まて高い強度を 維持すること，高いヤング率を持つこと，熱膨張率が小 さいことがわかった。しかし，彼らはその原因について は考察していない。また菅沼ら²) AC8Aアルミニウ ム合金/ほう酸アルミニウムウィスカ複合材の組織を透 過電子顕徽鏡によって調べた。その結果, ほう酸アルミ ニウムウィスカと AC8A アルミニウム合金溶湯との反 応は比較的激しく, ウィスカの表面に $\mathrm{MgAl}_{2} \mathrm{O}_{3}$ (一部 $\left.\gamma-\mathrm{Al}_{2} \mathrm{O}_{3}\right)$ が形成することがわかった。むた栃木ら4)は 3 種類のアルミニウム合金マトリックス（AC4A, AC8A, ADC12）を用いてほう酸アルミニウムウィスカ との複合材を作製し，強度に及ぽすマトリックスの影響

\footnotetext{
* 名古屋工業技術研究所 (名古屋市)。National Industrial Research Institute of Nagoya (Nagoya-shi, Aichi).
} 


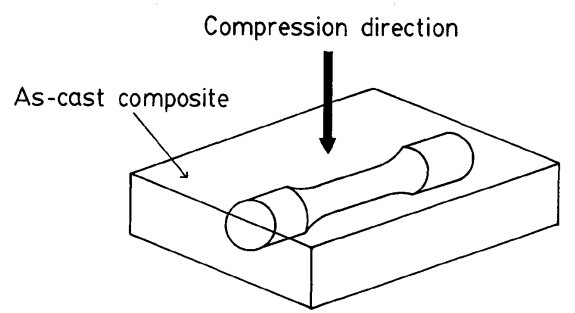

Fig. 1 Schematic illustration of the specimen orientation.

を調ベた。その結果，マトリックスの強度が増加すると 複合材の強度も増加することがわかった。

金属基複合材料のマトリックスとして時効析出型のア ルミニウム合金を用いた場合，一般には強度を上げるた めに溶体化・時效処理が行われる。したがって，アルミ ニウム合金基複合材料の機械的性質に対寸る溶体化 · 時 効処理の影響を調べることは重要である。しかし，この 点を調べた報告は土取ら゙によるものしかない。彼ら は, AC8Aアルミニウム合金/ 注ら酸アルミニウムウィ スカ複合材に時効処理（T6 処理）を施し，曲げ強度を 調べた。その結果，時効処理を行わない場合は曲げ強度 はマトリックス材に比べて150 MPa 増加したが，時効 処理を行うと逆に強度が100 MPa 低下寸ることがわか った。しかし，その原因についてはまだ不明なよらであ る。このように, ほら酸アルミニウムウィスカ強化アル ミニウム合金の特性を調べた研究，ことに機械的性質に 対する熱処理の影響に関しては報告例が少ない。

そこで本研究では, ほら酸アルミニウムウィスカ強化 アルミニウム合金を作製し，実用的に重要である機械的 性質に対する溶体化・時効処理の効果を調べた。今回は 機械的性質に対する溶体化・時効処理の効果が明瞭にで るよらに, マトリックスとして時効析出型の6061アルミ ニウム合金を用いた。

\section{2. 実験方法}

本研究では, ほう酸アルミニウムウィスカ（四国化成 工業製）を用いた。このウィスカは，長さが10〜30 $\mu \mathrm{m}$ と炭化けい素ウィスカや窒化けい素ウィスカに比べて短 い。また，炭化けい素ウィスカと同程度の剛性率を持 つ。このウィスカを蒸留水中またはエチルアルコール中 によく分散させ，吸引法でプリフォームを作製した。そ して加圧鋳造法により6061アルミニウム合金とウィスカ を複合化した。加圧条件は以前に報告したとおりであ る5)。

複合材中のウィスカの体積含有率 $\left(V_{f}\right)$ は16および $29 \mathrm{vol} \%$ であった。マトリックス金属としては時効析出 型の6061アルミニウム合金を用いた。Fig. 1 に試験片の

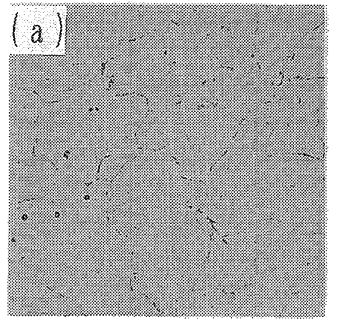

$100 \mu \mathrm{m}$

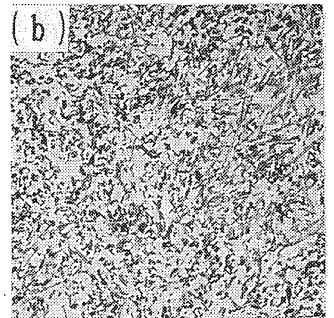

$40 \mu \mathrm{m}$
Fig. 2 Optical micrographs of (a) 6061 aluminum alloy, and (b) $9 \mathrm{Al}_{2} \mathrm{O}_{3} \cdot 2 \mathrm{~B}_{2} \mathrm{O}_{3}$ whisker $/ 6061$ aluminum alloy. Specimens are under the as-cast condition.

採取方向を示す。

試験前に，試料に溶体化および時効処理を施した。溶 体化は $833 \mathrm{~K}$ に $3.6 \mathrm{ks}$ 保持後, $273 \mathrm{~K}$ の水水中に落下. 急冷することで行った。溶体化後の試料は，時効処理を 行う直前まで液体窒素中に保存した。時効処理は, 443 Kのオイルバス中に所定の時間だけ保持することで行 った。なお，一部の試料は時効材との比較のために，熱 処理を行わずに as-cast の状態で試験に用いた。

as-cast 材については室温から773 K までの温度で引張 試験を行った。また時効材については, 最初にビッカー 不硬度測定によって時効硬化曲線を求め，時効条件を決 定した。そして，その後に所定の熱処理を施して，室温 のみで引張試験を行った。as-cast 材，時効材ともに， 引張試験後に破面をSEMによって観察した。

\section{3. 実験結果および考察}

\section{1 as-cast 材の引張試験}

Fig. 2 に加圧方向に垂直な面の6061アルミニウム合 金，および6061アルミニウム合金基複合材 $\left(V_{f}=0.29\right)$ の光学顕微鏡写真を示す。6061アルミニウム合金と比較 すると, 複合材では析出物や晶出物が非常に微細になっ ている。これらの析出物や晶出物は, 数 $\mu \mathrm{m}$ のオーダー の大きさでウィスカの間隙に均一に分布している。ま た，プリフォームを作製するときにウィスカが沈降する ので，この面（加圧方向に垂直な面）に平行なウィスカ が比較的多く観察される。

Fig. 3 に室温での as-cast 材の引張強度と複合材のウ ィスカ体積含有率 $\left(V_{f}\right)$ の関係を示す。この図からわか るように, 引張強度は $V_{f}$ の増加とともに増加する。す なわち，マトリックス材 $\left(V_{f}=0\right)$ では引張強度が 183 $\mathrm{MPa}$ であったが，0.29 $V_{f}$ 複合材では $350 \mathrm{MPa}$ とほぼ 2 倍の強度を示した。この結果より，ほう酸アルミニウム 


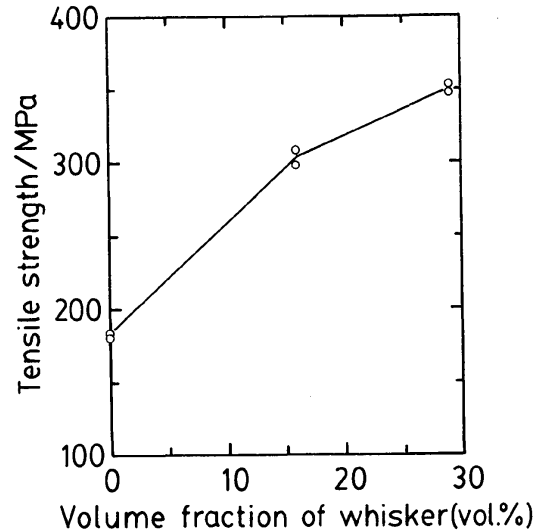

Fig. 3 Effect of the whisker volume fraction on the tensile strength of $9 \mathrm{Al}_{2} \mathrm{O}_{3} \cdot 2 \mathrm{~B}_{2} \mathrm{O}_{3}$ whisker/6061 aluminum alloys. Specimens are under the as-cast condition.

ウィスカはアルミニウム合金基複合材料用の強化材とし

て有効であると考觉られる。

またFig. 4 はマトリックス材と0.29 $V_{f}$ 複合材の室温 から773 K までの引張試験の結果である。この図からわ かるように, 複合化による強化の効果は $773 \mathrm{~K}$ をで維持 されている。つまりほら酸アルミニウムウィスカは7773 $\mathrm{K}$ までの温度域で, アルミニウム合金基複合材料用の 強化材として有効に作用する。

Fig. 5 は as-cast 材の室温での引張試験後の破面であ る。マトリックス材は延性破面を示している。また， $0.29 V_{f}$ 複合材の破面上にはプルアウトしたウィスカは 観察されない。この結果は, ほう酸アルミニウムウィス カとマトリックスの6061合金がよく濡れていることを示 している。

またFig. 6 およびFig.7はマトリックス材および $0.29 V_{f}$ 複合材の高温での引張試験後の破面である。試 験温度は, $373 \mathrm{~K}, 573 \mathrm{~K}$ および $773 \mathrm{~K}$ である。マトリッ クス材では373 K においても室温での場合と同様に延性

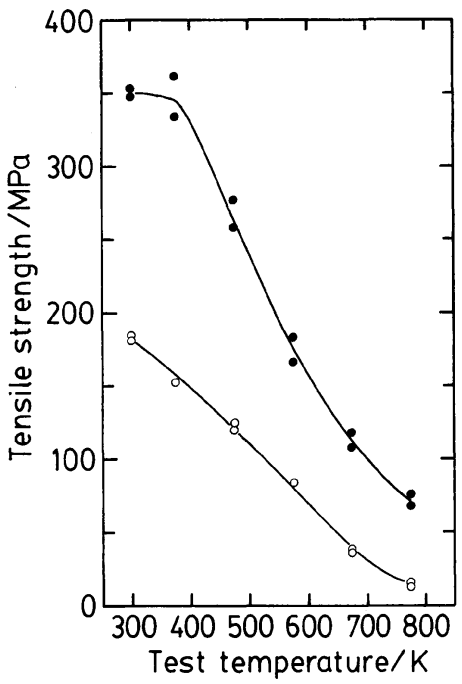

Fig. 4 Effect of temperature on the tensile strength of $9 \mathrm{Al}_{2} \mathrm{O}_{3} \cdot 2 \mathrm{~B}_{2} \mathrm{O}_{3}$ whisker $/ 6061$ aluminum alloys. Open mark (O) shows 6061 aluminum alloy, and solid mark $(\bullet)$ shows $9 \mathrm{Al}_{2} \mathrm{O}_{3} \cdot 2 \mathrm{~B}_{2} \mathrm{O}_{3}$ whisker $/ 6061$ aluminum alloy $\left(V_{f}=0.29\right)$. Specimens are under the as-cast condition.
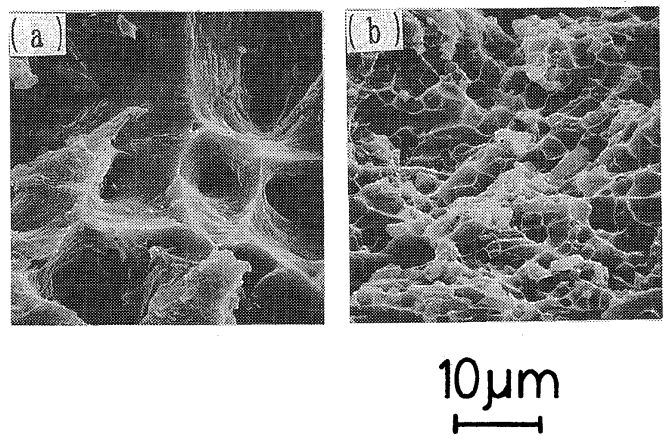

Fig. 5 SEM micrographs of fracture surfaces of (a) 6061 aluminum alloy, and (b) $9 \mathrm{Al}_{2} \mathrm{O}_{3} \cdot 2 \mathrm{~B}_{2} \mathrm{O}_{3}$ whisker/ 6061 aluminum alloy. Specimens were fractured at $300 \mathrm{~K}$.
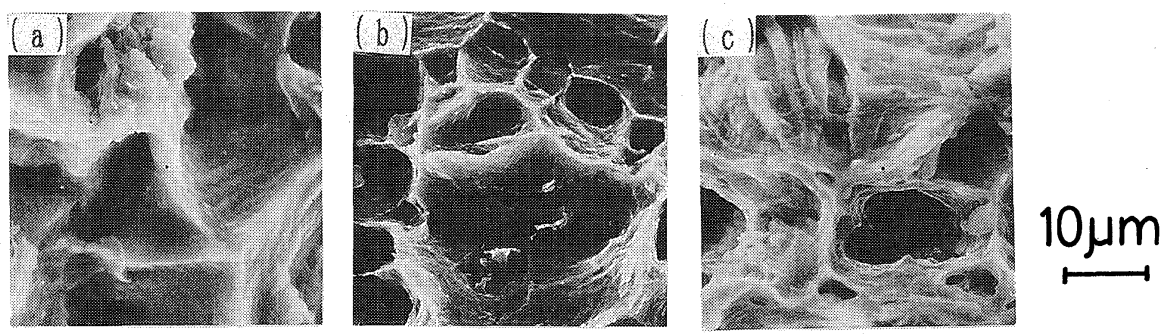

Fig. 6 SEM micrographs of fracture surfaces of 6061 aluminum alloys. Specimens were fractured at (a) $373 \mathrm{~K}$, (b) $573 \mathrm{~K}$ and (c) $773 \mathrm{~K}$. 

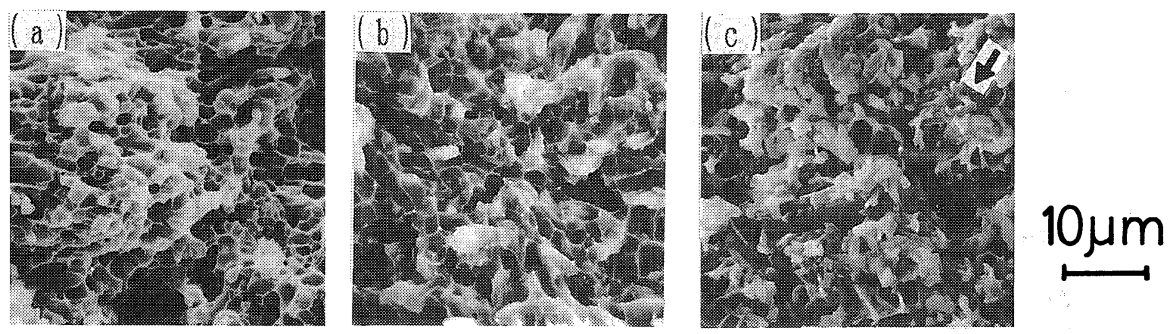

Fig. $7 \mathrm{SEM}$ micrographs of $9 \mathrm{Al}_{2} \mathrm{O}_{3} \cdot 2 \mathrm{~B}_{2} \mathrm{O}_{3}$ whisker/6061 aluminum alloy. Specimens were fractured at (a) $373 \mathrm{~K}$, (b) $573 \mathrm{~K}$ and (c) $773 \mathrm{~K}$.

破面を示している。そして, 温度が上昇しても破面の様 子は大きく変化しない。それに対して，0.29 $V_{f}$ 複合材 では温度の上昇とともに破面の様子が変化した。 $573 \mathrm{~K}$ までは室温での破壊と同様に，破面上にウィスカのプル アウトは観察されない。しかし773 K では，矢印で示し たように破面上にウィスカとマトリックスの剥離した跡 が観察される。このような，室温と高温での破面の違い はNieh ら6よってても報告されている。

光学顕微鏡観察および破面観察の結果から, $0.29 V_{f}$ 複合材ではウィスカとマトリックスの濡れがよいこと， 析出物がマトリックス単体の場合に比べて微細化してい ることがわかった。これらはいずれも材料の強度を高め る因子である。すなわち，このようなマトリックス側の 強化とウィスカによる強化の両方の効果によって, $0.29 V_{f}$ 複合材の強度が向上すると考えられる。

\section{2 時効材の引張試験}

3.1 で述べたように, as-cast 状態では，ほう酸アルミ ニウムウィスカは773 K までの温度域で, アルミニウム 合金基複合材料用の強化材として有効に作用することが わかった。そこで次に，㴗ら酸アルミニウムウィスカ強 化アルミニウム合金の強度に対する溶体化・時効処理の 効果を調べた。

まず時効時間を決定するために、トリックス材およ び0.29 V 複合材の時効硬化曲線を求めた。その結果を Fig. 8 に示す。マトリックス材， $0.29 V_{f}$ 複合材ともに 時効硬化挙動を示している。しかし硬化速度は，0.29 $V_{f}$ 複合材の方がマトリックス材に比べて速くなっている。 すなわち，マトリックス材では硬度が最大になるまで $180 \mathrm{ks}$ かかっているが， $0.29 V_{f}$ 複合材では $3 \mathrm{ks}$ しかか かっていない。このような, 複合材に拈ける硬化速度の 増加は他の研究者によっても報告されている7),8

硬度測定の結果を基に，マトリックス材と $0.29 V_{f}$ 複 合材に， peak-aging 状態と over-aging 状態になるように 時効処理を行い室温で引張試験を行った。時効時間は次 のとおりである。 peak-aging 状態の場合はマトリックス 材は90 ks, $0.29 V_{f}$ 複合材は $3 \mathrm{ks}$ とした。また over-ag-

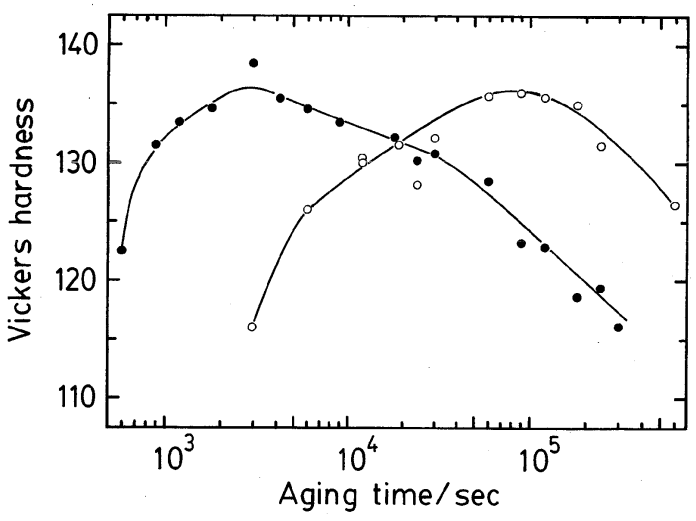

Fig. 8 Relationship between Vickers hardness and aging time. Open mark (O) shows 6061 aluminum alloy, and solid mark (-) shows $9 \mathrm{Al}_{2} \mathrm{O}_{3} \cdot 2 \mathrm{~B}_{2} \mathrm{O}_{3}$ whisker/6061 aluminum alloy $\left(V_{f}=0.29\right)$. Specimens were aged at $443 \mathrm{~K}$.

Table 1 Relationship between specimen condition and tensile strength

\begin{tabular}{l|c|c|c}
\hline \hline & \multicolumn{3}{|c}{ Tensile strength (MPa) } \\
\cline { 2 - 4 } & $\begin{array}{c}\text { as-cast } \\
\text { condition }\end{array}$ & $\begin{array}{c}\text { peak-aging } \\
\text { condition }\end{array}$ & $\begin{array}{c}\text { over-aging } \\
\text { condition }\end{array}$ \\
\hline $\begin{array}{l}6061 \text { aluminum } \\
\text { alloy }\end{array}$ & 182 & 376 & 366 \\
$0.29 V_{f}$ composite & 350 & 393 & 356 \\
\hline
\end{tabular}

ing 状態の場合はマトリックス材は $600 \mathrm{ks}, 0.29 V_{f}$ 複合 材の場合は $300 \mathrm{ks}$ とした。

Table 1 に, 時効材の引張強度と時効条件の関係を示 す。この表より，マトリックス材， $0.29 V_{f}$ 複合材とも peak-aging 状態では as-cast 状態よりも強度が増加する ことがわかる。また over-aging 状態では，いずれの試料 でも強度はやや減少する。しかし peak-aging 状態での 強度の増加の割合に注目すると, マトリックス材と $0.29 V_{f}$ 複合材では違いがある。つまり, マトリックス 材では peak-aging 状態では強度が376 MPa と as-cast 状 

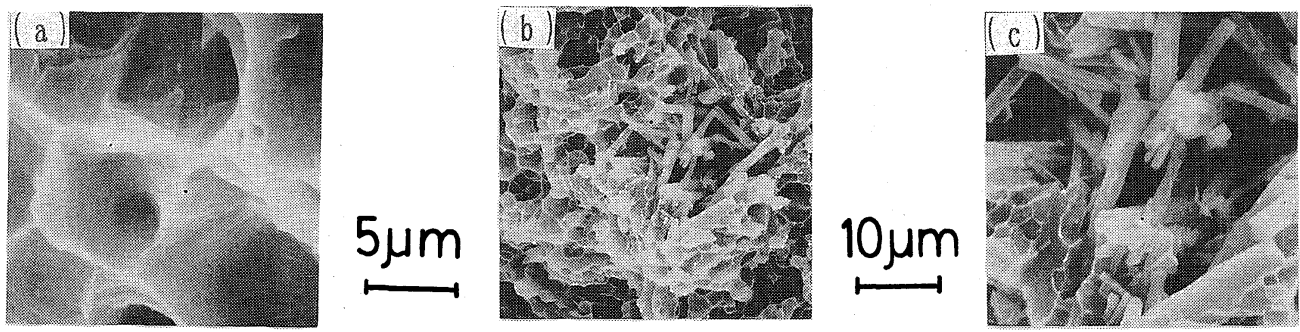

$5 \mu m$

Fig. 9 SEM micrographs of fracture surfaces of (a) 6061 aluminum alloy, and (b), (c) $9 \mathrm{Al}_{2} \mathrm{O}_{3} \cdot 2 \mathrm{~B}_{2} \mathrm{O}_{3}$ whisker $/ 6061$ aluminum alloy. Specimens are under the peak-aging condition.

態の強度のほぼ 2 倍を示した。しかし，0.29 V 複合材 では強度が393 MPa とほぼ1.2倍の増加しか示さない。

Fig. 9 は peak-aging 状態の試料の引張試験後の破面 である。マトリックス材では as-cast 状態と同じように 粒内延性破壊を示している。それに対して，0.29 $V_{f}$ 複 合材では破面の様子は as-cast 状態とは大きく異なる。 すなわち，as-cast 状態では存在しなかったウィスカと マトリックスの剥離した跡が多数観察された。このこと は, 溶体化・時効処理を行うとウィスカとマトリックス の界面の強度が低下し，その結果として試料が脆化する ことを示している。

これらの結果から, peak-aging 状態で0.29 $V_{f}$ 複合材 の方がマトリックス材に比べて強度の増加の割合が小さ い原因は次のように定性的に説明される。 as-cast 状態 では，ウィスカとマトリックスの良好な濡れ性，析出物 の微細化によって複合材の強度は増加した。しかし peak-aging 状態では，これらの材料の強度を高める因子 と同時に, ウィスカとマトリックスの界面の強度の低下 といら材料の強度を弱める因子が生じる。このように強 度を高める因子と弱める因子が生じるので, peak-aging 状態における強度の増加の割合は， $0.29 V_{f}$ 複合材の方 がマトリックス材に比べて小さくなる。

今回の実験では, 溶体化・時効処理によって注う酸ア ルミニウムウィスカと6061アルミニウム合金の界面強度 が低下する原因までは特定できなかった。しかし今後， ほう酸アルミニウムウィスカをアルミニウム合金基複合 材料用の強化材として用いるためには, 溶体化・時効処 理によるウィスカとマトリックスの界面の強度の低下の 原因の解明および適切なマトリックスの選択が必要であ ると思われる。これらの点については，現在検討中であ る。

\section{4. 結言}

注ら酸アルミニウムウィスカと6061アルミニウム合金
の複合材を加圧鋳造法によって作製し，引張試験を行っ た。その結果，以下のことがわかった。

(1) as-cast 状態では0.29 $V_{f}$ 複合材はマトリックス材 の約 2 倍の強度を持つ。また，ウィスカとマトリックス の濡れは良好であった。

（2） $0.29 V_{f}$ 複合材の複合化による強度の増加は，773 $\mathrm{K}$ まで維持される。

（3）硬化速度は0.29 $V_{f}$ 複合材の方がマトリックス材 に比べて速い。

(4) peak-aging 状態では，マトリックス材も0.29 $V_{f}$ 複合材も as-cast 状態に比べて強度が増加した。しかし， 増加の割合は0.29 $V_{f}$ 複合材の方が小さかった。

（5）溶体化·時効処理を行うと，ウィスカとマトリッ クスの界面の強度が低下する。

最後に，複合材の作製に協力していただいた当所金属 部主任研究官 ·井沢紀久氏に感謝します。また，実験に 協力された愛知工業大学学生・池上純氏に感謝します。

\section{参 考 文 献}

1）菅沼克昭，藤田輝昭，佐々木元，鈴木信幸：軽金属， 41 (1991)， 270.

2）菅沼克昭，佐々木元，藤田輝昭，鈴木信幸：軽金属， 41 (1991)， 297.

3）土取 功, 中村和清, 新田 明, 筒本隆博 : 日本金 属学会1991年度秋期講演会概要集, 421.

4）栃木 勲, 愛 恭輔, 佐野明彦：日本金属学会1991 年度秋期講演会概要集， 430 。

5）松原弘美，西田義則，白柳 格，山田 守：軽金属, 39 (1989), 338.

6) T. G. Nieh, C. G. Henshall and J. Wadsworth: Scripta met., 18 (1984), 1405.

7) T. Ghristman and S. Suresh: Acta Metall., 36 (1988), 1691.

8) T. Christman, A. Needlman, S. Natt and S. Suresh Mater. Sci. and Eng., A107 (1989), 49. 